International Journal of Agriculture, Environment and Bioresearch

Vol. 4, No. 04; 2019

ISSN: $2456-8643$

\title{
COMPARISON OF COMBINED FILTER AND ACTIVATED CARBON ON TREATMENT OF SYNTHETIC GREYWATER BY PRODUCED MGCL2 BASED ACTIVATED CARBON FROM RICE STRAW WASTE
}

\author{
Ali Akbar Babar'; Sheeraz Ahmed Memon ${ }^{1}$; Muhammad Faizer Ali ${ }^{\text {* }}$ and Farooq Ahmed Memon ${ }^{1}$ \\ 1 Institute of Environmental Engineering and Management, Mehran University of Engineering \& Technology, \\ Jamshoro, Sindh, Pakistan, Postal 76062. \\ http://doi.org/10.35410/IJAEB.2019.4412
}

\begin{abstract}
The aim of the study was to provide an opportunity to reuse of grey water after treatment in order to overcome the scarcity of freshwater in Pakistan. Treated grey water can be reliable source for consumption i.e. landscape, public parks and irrigation etc. Rice straw is considered as a waste material globally and burnt at fields after harvesting of paddy rice so it was used as a raw material to produce both the filters. It is stated that activated carbon (AC) prepared by agroindustrial waste are considered as low-cost generated as compared to industrially prepared activated carbon. Activated carbon was prepared in a muffle furnace and added activating agent $(\mathrm{MgCl} 2)$ in an inert atmosphere at the temperature 550 o $\mathrm{C}$ for two hours. Filters for application were fabricated by two different methods, one was filled by activated carbon and the other one partially filled by rice straw and remaining space was filled by activated carbon. Efficiency of both the filters was assessed by application on synthetic grey water. The FTIR results of $\mathrm{MgCl} 2$ Based activated carbon showed 6 peaks which confirms the attachment of aromatics, carboxylic acids, amides, and miscellaneous classes on the surface. Whereas, FTIR of rice straw showed the functional groups of amines, aromatic, alkanes, alkanes and amines so it is concluded that different peaks have the same functional groups but with different structures. While the XRD analysis of produced activated carbon showed the peaks between 10 to $40 \mathrm{o}$ which is the confirmations of the amorphous crystalline structure and residual ash whereas rice straw XRD results shows that it is crystalline structure and having good stability for adsorption. Furthermore, SEM images authenticated the XRD results by showing the presence of $\mathrm{MgCl} 2$ on the surface of activated carbon. It was also concluded from SEM micrographs that the high temperature and activating agent influences the structure of biomass (Rice Straw) and helps in converting it into a more use full material. SEM images of rice straw are showing uniform structure and a series of tunnels. Magnification in SEM at 3000, sub-pores were observed with the irregular shape and smooth surface. It was concluded that combined filter is more efficient than the activated carbon filter which has significantly removed BOD5, COD, TSS, Turbidity and Oil \& Fats up to $93 \%, 92 \%, 75 \%, 91 \%$ and $93 \%$, respectively and $\mathrm{pH}$ of the synthetic grey water was neutralized from 9.2 to 7.8 by combined filter whereas activated carbon has neutralized up to 8.0.
\end{abstract}


Keywords: Rice Straw (RS), activated carbon (AC), $\mathrm{MgCl} 2$, Biomass, Greywater Treatment, Combined Filter.

\section{INTRODUCTION}

Nowadays availability of fresh water in the world is less than $1 \%$. Depletion of fresh water is increasing day by day and nowadays it has become environmental concern globally [1]. It was predicted that population will be increased to 9 billion in 2050 so the consumption of fresh water will also be increased [2]. This leads to adopt and introduce new technologies of extracting fresh water from wastewater or grey-water for industrial and agricultural usage [3]. Pakistan totally depends upon snowmelt and rainfall for restoration of fresh water resources [4]. As reported by UNO Pakistan is $7^{\text {th }}$ number in the list of water stressed countries, resources of fresh water are only 177 MAF including 14\% underground water and $86 \%$ surface-water. The studies were carried out and concluded that Pakistan might be facing 33 MAF fresh water scarcities by 2025 [5]. All sources from domestic wastewater except black-water (wastewater from toilets) is called as grey water, which is very important in developing countries. The improper disposal of wastewater is main cause of fatal diseases as well as environmental pollution [6]. Proper management of grey water includes gathering and recycling after treatment to avoid individuals in contact with it and restricts transfer of pathogens, the treatments of water bodies has positive roll to reduce nutrients and also eutrophication [7]. The recycling of grey water is experienced in all over the world to increase the availability of water and protects human health and beneficial for other environmental aspects [8]. Treated grey-water can be reliable source for consumption. Grey-water contains up to $70 \%$ of water, approximately $30 \%$ of organic fraction and 9 to $20 \%$ nutrients [9]. The treated water is mostly consumed for non-potable (not for drinking) purposes, such as landscape, public parks and irrigation etc. Furthermore non-potable water includes coolant for power plants or oil refineries and also for other industrial processes [10]. There are various methods to treat the grey water but adsorption is the method which is believed as an efficient and economical method for the treatment of grey water. It is also favored because it does not produce sludge [11]. The adsorbent is considered cost-effective if it is produced from natural resources or any waste material such as agriculture waste, [12]. In industrial point of view activated carbon is the considered as significant adsorbent [13]. Activated carbon is a complex porous structure which has energetic as well as chemical inhomogeneity. It was challenge to produce a low cost activated carbon with distinct pore sizes at low temperature [14]. There are many natural resources to produce high specific surface area and pore volume carbonaceous materials such as coconut shells, bagasse from sugarcane industries, coal, cotton stalks, rice husk, wood [15-19], etc. Rice straw is produced as a byproduct of rice crop and considered as agriculture residue. Rice straw is roughly produced 800 to 1,000 million tons per year, globally [20]. There are two processes for the production of activated carbon; chemical activation and physical activation. Single stage method of activated carbon in presence of chemical agent is known as chemical activation and a carbonaceous material followed by activation of prepared charcoal in presence of activating agent such as $\mathrm{FeCl}_{3}$ or steam is known as two stage method [21]. There are different temperatures are used to produce activated carbon and different chemical activating agents are also used to activate such as $\mathrm{KOH}$ and $\mathrm{K}_{2} \mathrm{CO}_{3}$ [22], $\mathrm{H}_{3} \mathrm{PO}_{4}$ and $\mathrm{ZnCl}_{3}$ [23]. 


\section{MATERIALS AND METHODS}

\subsection{Preparation of rice straw}

Initially, rice straw was shorten into small pieces of $1.5 \mathrm{~cm}$ and then washed to remove dirt and other impurities. Furthermore, it was dried in an oven at $105^{\circ} \mathrm{C}$ for 24 hourstodehydrate. The material was prepared for both combined filter (RS \& AC) and activated carbon filter [24].

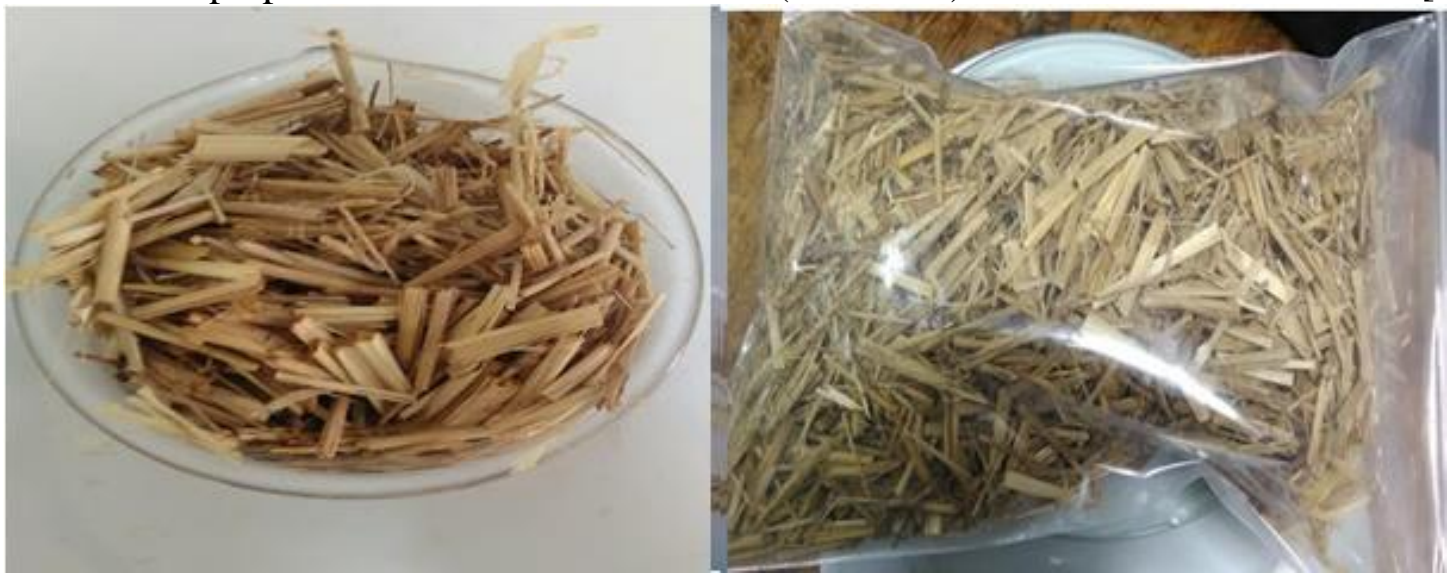

Figure 1:Raw material (Rice Straw).

\subsection{Preparation of activated carbon}

Preparation was started with impregnation ofwith an activating agent $\left(\mathrm{MgCl}_{2}\right)$ 1:1 by weight then oven dried at $105{ }^{\circ} \mathrm{C}$ for 48 hours.For activation it was filled in crucibles having volume $100 \mathrm{ml}$ and these crucibles were placed in steel container containing sand to create an inert atmosphere.Container was thencovered with airtight lidfor pyrolysis in a muffle furnace at $550{ }^{\circ} \mathrm{C}$ for 2 hours. After this process steel container was taken out from the muffle furnace and kept atroom temperature for cooling [25].

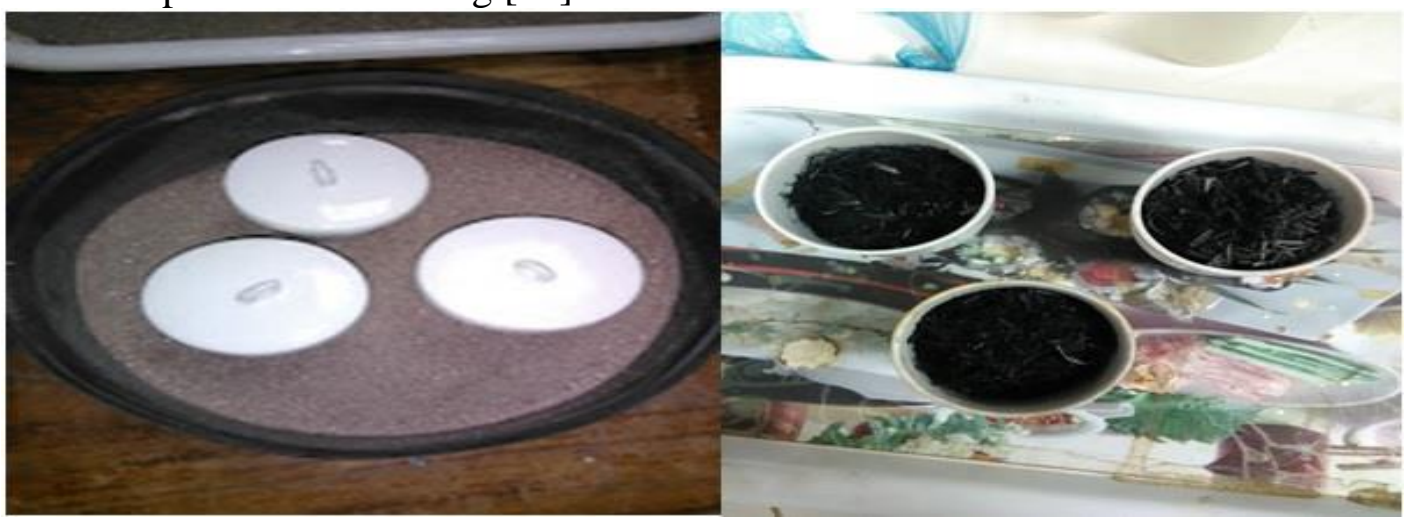

Figure 2: Crucible and steel container used for activated carbon.

\section{CHARACTERIZATION OF ACTIVATED CARBON}

\subsection{Furrier Transform Infrared Spectroscopy (FTIR)}

The equipment used for the FTIR spectrometer Analyzation was Thermo Nicolet 6700 having a changeable $\mathrm{KBr}$ optic and a detector made up of deuterated triglycine sulfate (DTGS) to examine 
the standard pellets and samples. The standard regions of examination taken for all spectra were in mid-infrared (IR) of 4000-400 $\mathrm{cm}^{-1}$ having the resolution of $4 \mathrm{~cm}^{-1}$ with the accumulation rate 32 scans per spectra.

\subsection{X-Ray Diffraction(XRD)}

XRD analysis was carried by Philips XRD instrument, equipped with Cuka radiations of $40 \mathrm{KV}$ and $30 \mathrm{~mA}$, and having 2-theta of step size $0.05^{\circ}$. The scanning rate employed for spectra measure was $1 \%$ minute.

\subsection{Scanning Electron Microscopy(SEM)}

Morphology, structure, and composition of nanostructures formed on the surface of activated carbon was observed by using SEM micrographs obtained on a JEOL, Tokyo, Japan machine.

\section{PREPARATION OF SYNTHETIC GREY WATER}

Synthetic greywaterwas prepared by usingdifferent ingredients such asAmmonium Chloride $\left(\mathrm{NH}_{4} \mathrm{Cl}\right)$, Backing Yeast $\left(\mathrm{C}_{19} \mathrm{H}_{14} \mathrm{O}_{2}\right)$, Sodium carbonate $\left(\mathrm{Na}_{2} \mathrm{CO}_{3}\right)$, Flour (fine grinded), Shower gel, Detergent powder, Polysaccharides $\left(\left(\mathrm{C}_{6} \mathrm{H}_{10} \mathrm{O}_{5}\right)\right.$ n), Cooking oil, Sewage, Potassium Sulfate $\left(\mathrm{K}_{2} \mathrm{SO}_{4}\right)$ and sodium DiHydrogen Phosphate which are shown in (Table 1) [26].

Table 1: List of synthetic grey water ingredients

\begin{tabular}{|c|c|c|}
\hline Chemical Name & Concentration & Chemical formula \\
\hline Polysaccharides & 425 milligram Liter & $\left(\mathrm{C}_{6} \mathrm{H}_{10} \mathrm{O}_{5}\right) \mathrm{n}$ \\
\hline Ammonium Chloride & 375 milligram Liter & -5 \\
\hline Backing Yeast & 350 milligram Liter & $\mathrm{NH}$ \\
\hline $\mathrm{Cl}$ & - \\
\hline Flour (fine grinded) & 275 milligram Liter & - \\
\hline Sodium Carbonate & 275 milligram Liter & - \\
\hline Detergent powder & 150 milligram Liter & $\mathrm{Na}_{2} \mathrm{CO}_{3}$ \\
\hline Sodium Dihydrogen phosphate & 57. milligram Liter & $\mathrm{N}^{-5}$ \\
\hline Potassium sulfate & 22.5 milligram Liter & $\mathrm{NaH}_{2} \mathrm{PO}_{4}$ \\
\hline Sewage & 50 milligram Liter & $\mathrm{K}_{2} \mathrm{SO}_{4}$ \\
\hline Shower Gel & 0.5 millilitre & - \\
\hline Cooking oil & 0.5 millilitre $^{-5}$ & - \\
\hline
\end{tabular}




\section{FABRICATION OF DESIGNED MODEL}

Transparent glass tank (as shown in figure. 3) was installed on the top of designed model for sedimentation purpose, which has volumetric capacity of 40 litres. Then both the filterswere installed below the tank along with controlled valve for inlet and outlet flow. Columns were $50 \mathrm{cmlong}$ having $2 \mathrm{~cm}$ diameter. One column was filled with activated carbon and other with activated carbon and rice straw (Combined filter). Synthetic grey water was left for 3 hours to settle down then passed by both filters separately and samples were collected in containers. Diagram of designed model is shown in figure (4).

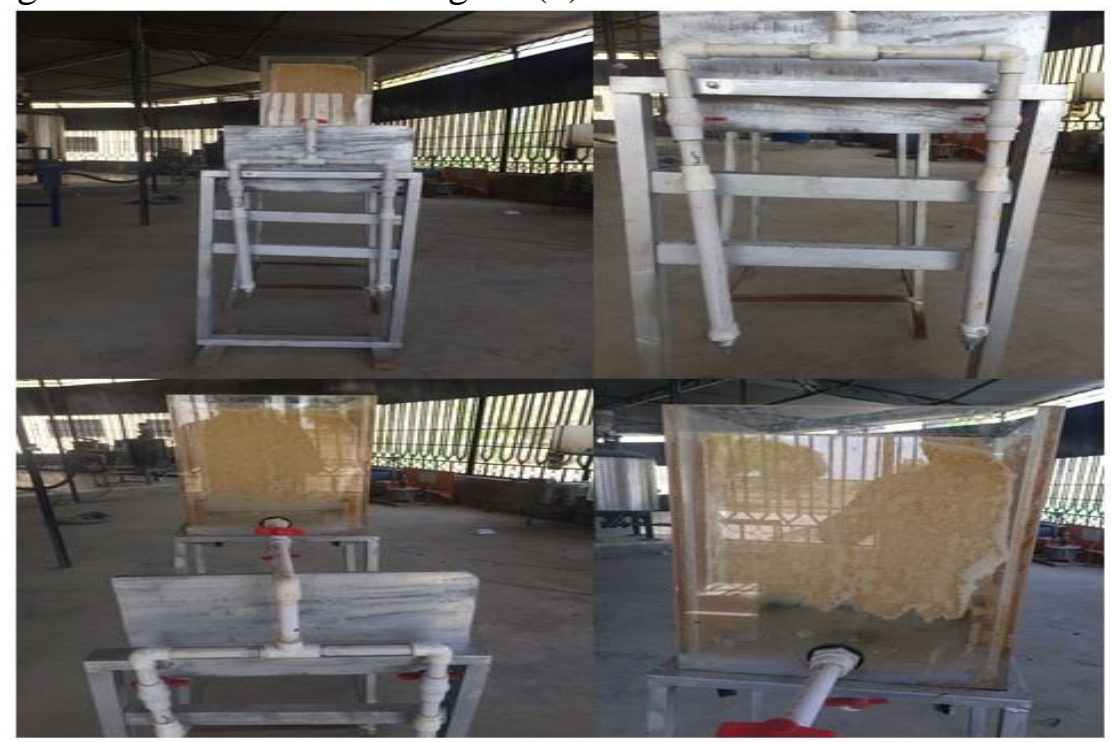

Figure 3: Designed model

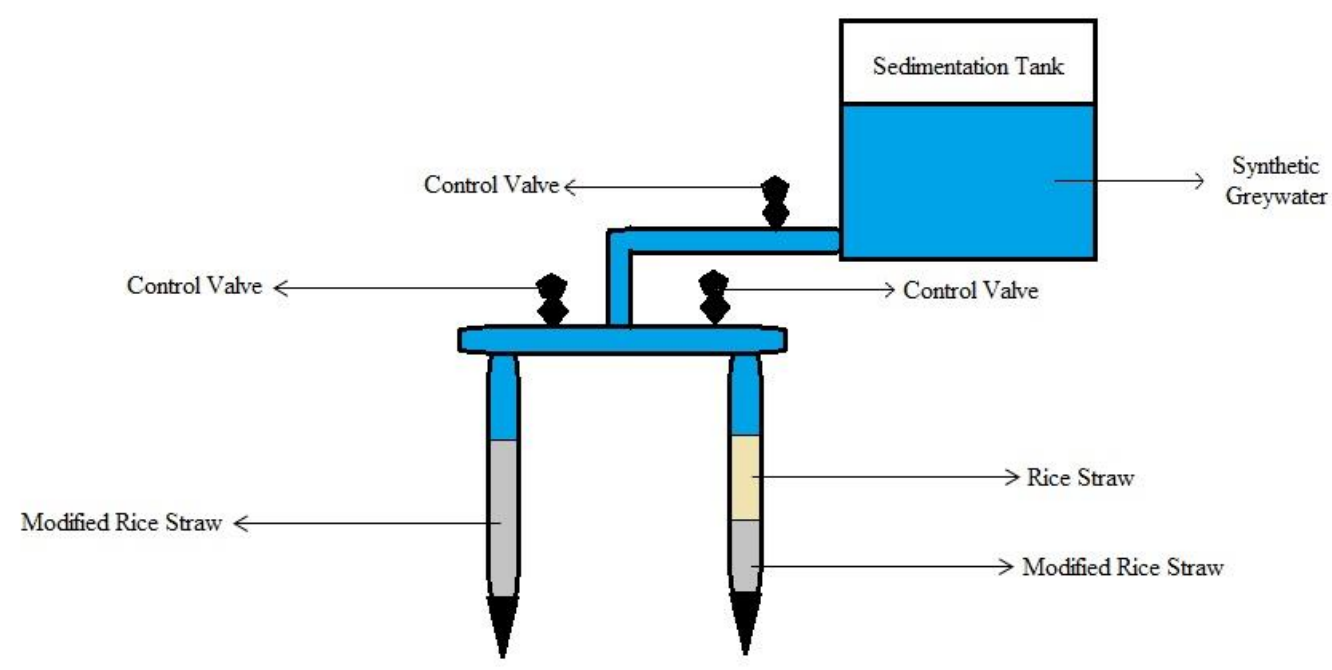

Figure 4: Diagram of designed model

\section{RESULTS AND DISCUSSIONS}




\subsection{FTIR results for Activated Carbon}

Rice straw activated carbon showed different peaks, 711 and $873 \mathrm{~cm}^{-1}$ are identifying aromatic class while the assignment of that peaks was $\mathrm{C}-\mathrm{H}$ out of plan as discussed by Coates [27]. Whereas, $1062 \mathrm{~cm}^{-1}$ bend shows carboxylic group having $\mathrm{RCO}-\mathrm{OH}$ structure and C-O assignments corresponding with Yeasmin and Mondal [28]. As stated by You [29] that $1633 \mathrm{~cm}^{-}$ ${ }^{1}$ has amides group and having structure RCONH2. Furthermore, miscellaneous substances observed at peak $2351 \mathrm{~cm}^{-1}$ having $\mathrm{P}-\mathrm{H}$ phosphine and assignment were $\mathrm{P}-\mathrm{H}$ phosphine sharp are matching with Javadian and Taghavi [30]. It was described by Bhuiyan [31] that $3265 \mathrm{~cm}^{-1}$ peaks have a carboxylic group having $\mathrm{RCO}-\mathrm{OH}$ structure and dimer $\mathrm{OH}$ assignment.

Table 2: FTIR results of rice straw activated carbon.

\begin{tabular}{|l|c|c|c|c|}
\hline S.No. & Peaks & Class & Structure & \multirow{2}{*}{ Assignment } \\
\hline 1 & $711 \mathrm{~cm}^{-1}$ & \multirow{2}{*}{ Aromatics } & $1,2,3$ tri-substance & \multirow{2}{*}{ C-H put plane } \\
\cline { 1 - 2 } 2 & $873 \mathrm{~cm}^{-1}$ & & $1,2,4$ tri-substance & \\
\hline 3 & $1062 \mathrm{~cm}^{-1}$ & Carboxylic acid & RCO-OH & C-O stretch \\
\hline 4 & $1633 \mathrm{~cm}^{-1}$ & Amides & RCONH2 & NH out of the plane \\
\hline 5 & $2351 \mathrm{~cm}^{-1}$ & Miscellaneous & P-H phosphine & P-H phosphine sharp \\
\hline 6 & $3265 \mathrm{~cm}^{-1}$ & Carboxylic Acid & RCO-OH & Dimer OH \\
\hline
\end{tabular}

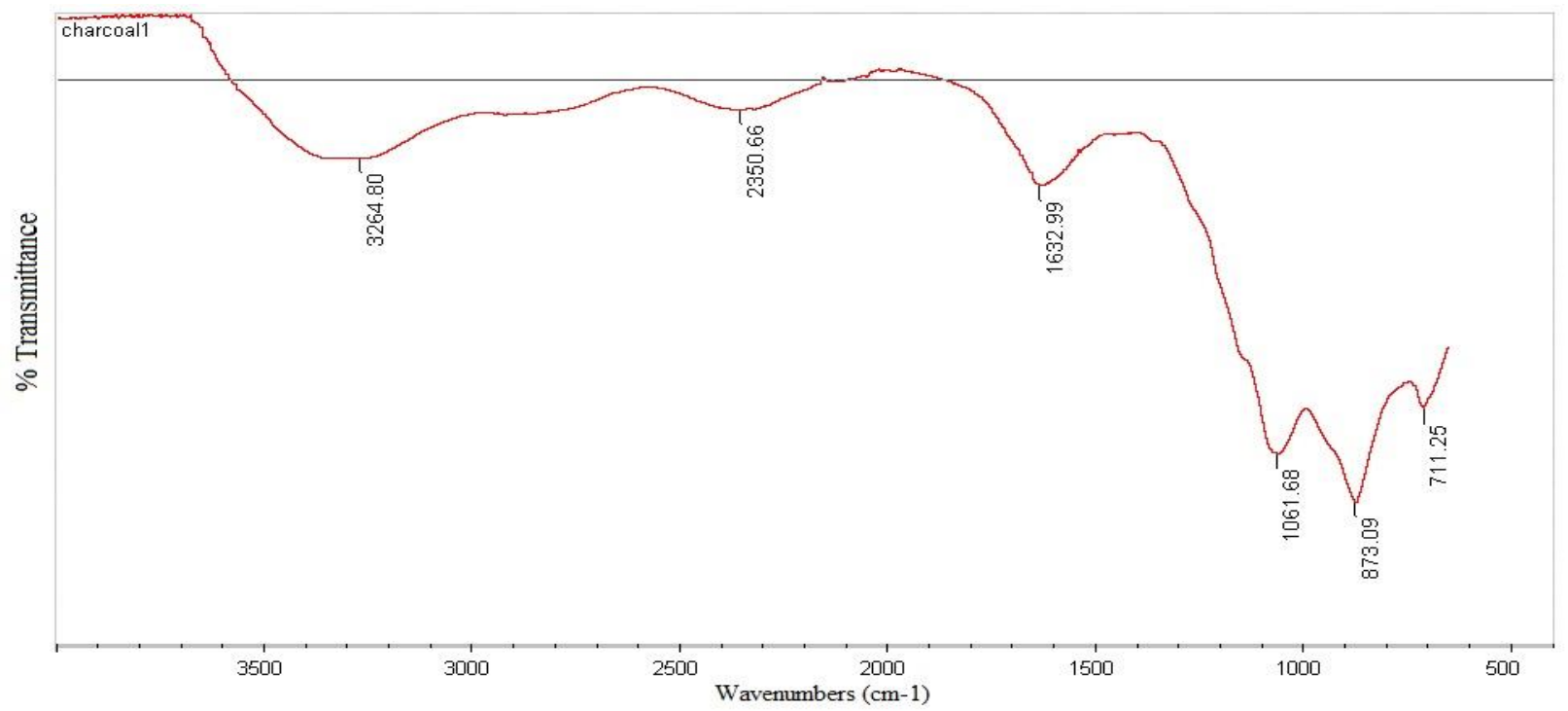

\subsection{FTIR results for rice straw}

Figure5: FTIR Peaks of Activated Carbon.

The FTIR peaks of rice straw were observed within the range of $400-4000 \mathrm{~cm}^{-1}$. The firstpeak at $1034 \mathrm{~cm}^{-1}$ is showing amines functional group having the $\mathrm{R}_{2} \mathrm{NH}$ structure with strong intensity and $\mathrm{C}-\mathrm{N}$ stretch as discussed by, Sim [32]. The peak at $1421 \mathrm{~cm}^{-1}$ showsaromatic functional group with $\mathrm{C}-\mathrm{C}$ in the ring structure and medium intensity, same results were discussed by Chen [33]. Peak at $1621 \mathrm{~cm}^{-1}$ showing a functional group of alkanes having $\mathrm{Ar}-\mathrm{CH}=\mathrm{CHR}$ structure and strong intensity, however, same peaks were observed by Aggarwal [34]. Spectrum at $2919 \mathrm{~cm}^{-1}$ showing a functional group of alkanes having $\mathrm{RCH}_{2} \mathrm{CH}_{3}$ structure and $\mathrm{CHstretch}$ which are too 
weak and low in frequency as observed by Musa [35]. The last peak at $3345 \mathrm{~cm}^{-1}$ shows amines functional group having an $\mathrm{R}_{2} \mathrm{NH}$ structure with weak intensity and stretching at $\mathrm{NH}$, as described by Tay [36].

Table 3: FTIR results of rice straw

\begin{tabular}{|c|c|c|c|c|}
\hline S.No. & Peaks & Class & Structure & Assignment \\
\hline 1. & $1034 \mathrm{~cm}^{-1}$ & Amines & $\mathrm{R}_{2} \mathrm{NH}$ & C-N stretch \\
\hline 2. & $1421 \mathrm{~cm}^{-1}$ & Aromatic & $\mathrm{C}-\mathrm{C}$ in ring & Ar C-C stretch \\
\hline 3. & $1621 \mathrm{~cm}^{-1}$ & Alkanes & Ar-CH=CHR & - \\
\hline 4. & $2919 \mathrm{~cm}^{-1}$ & Alkanes & $\mathrm{RCH}_{2} \mathrm{CH}_{3}$ & CH stretch \\
\hline 5. & $3345 \mathrm{~cm}^{-1}$ & Amines & $\mathrm{R}_{2} \mathrm{NH}$ & NH stretch \\
\hline
\end{tabular}

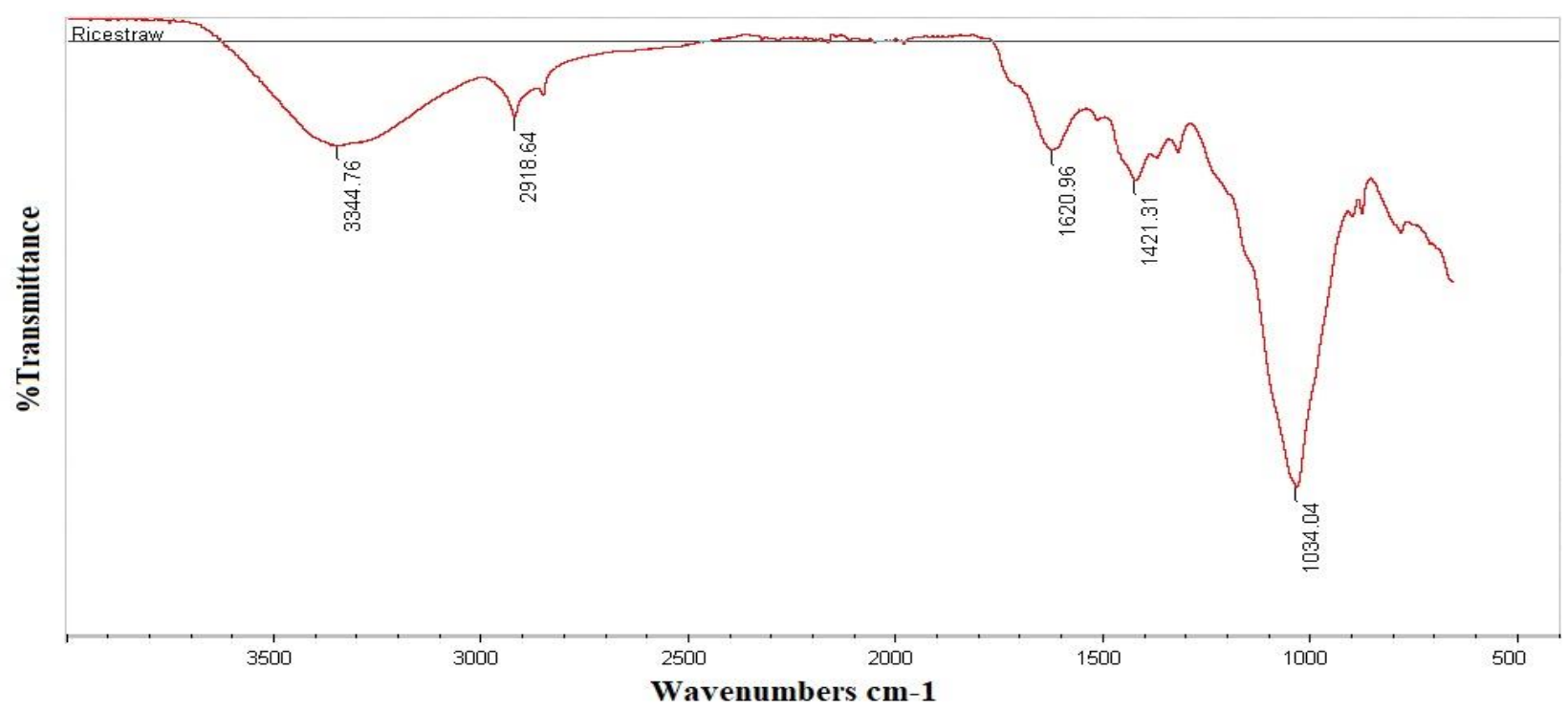

Figure 6: FTIR peaks of rice straw

\subsection{XRD results for Activated Carbon}

The crystalline structure of $\mathrm{MgCl}_{2}$-Based activated charcoal was analyzed with X-Ray Diffraction (shown in fig. 7). The three peaks were observed $2 \theta=10^{\circ}, 2 \theta=15^{\circ}$ and $2 \theta=40^{\circ}$ were confirming that activated carbon has an amorphous structure and sharp peaks having continuous pattern are identifying the existence of remaining ash and bits of metal in amorphous shape. The $\mathrm{MgCl} 2$ based charcoal's X-Ray Diffraction examinations are suggesting that some amount of $\mathrm{MgCl} 2$ existed in the adsorbent. From 3 peaks it was clarified that extracted adsorbent from rice straw didn't fall totally in the crystalline group. Whereas the main part of activated carbonshows graphite nature. The size of the adsorbent was ranging in 8-20 $\mathrm{nm}$ [31]. 
International Journal of Agriculture, Environment and Bioresearch

Vol. 4, No. 04; 2019

ISSN: $2456-8643$

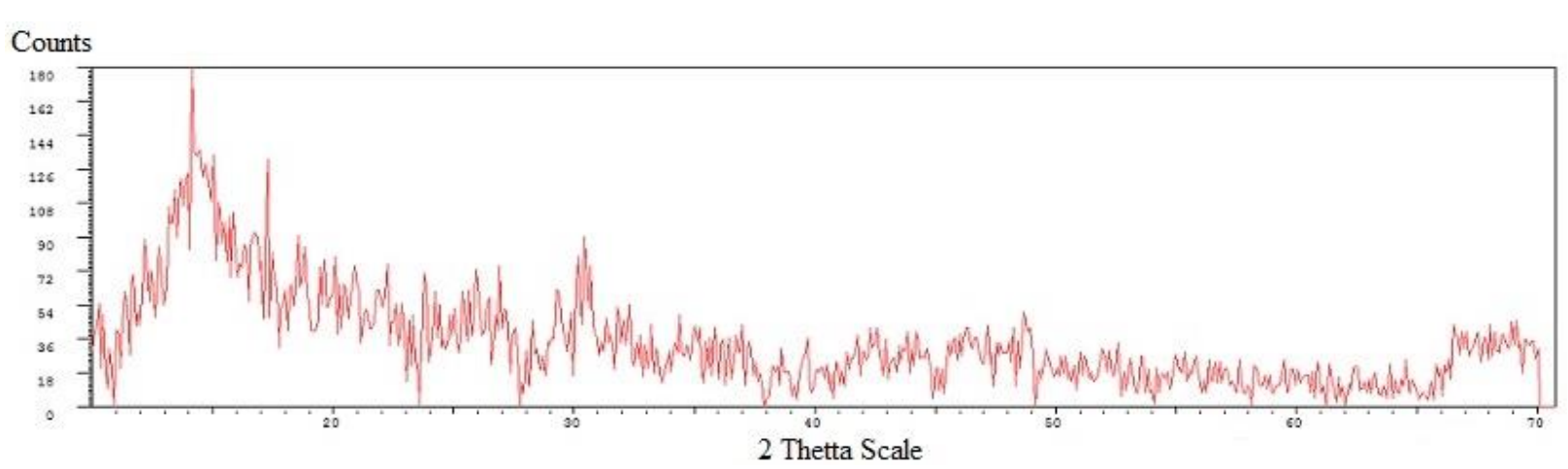

Figure 7: X-Ray Diffraction pattern of activated carbon.

\subsection{XRD results for Rice Straw}

The peak observed from $2 \theta$ to $20^{\circ}$ theta are determining that rice straw was a crystalline material and $2 \theta=25^{\circ}$ is showing the presence of silica, [37] anda continuous spectrum after $25^{\circ}$ in theta scale showing that rice straw material has good stability for adsorption process as discussed by[38].

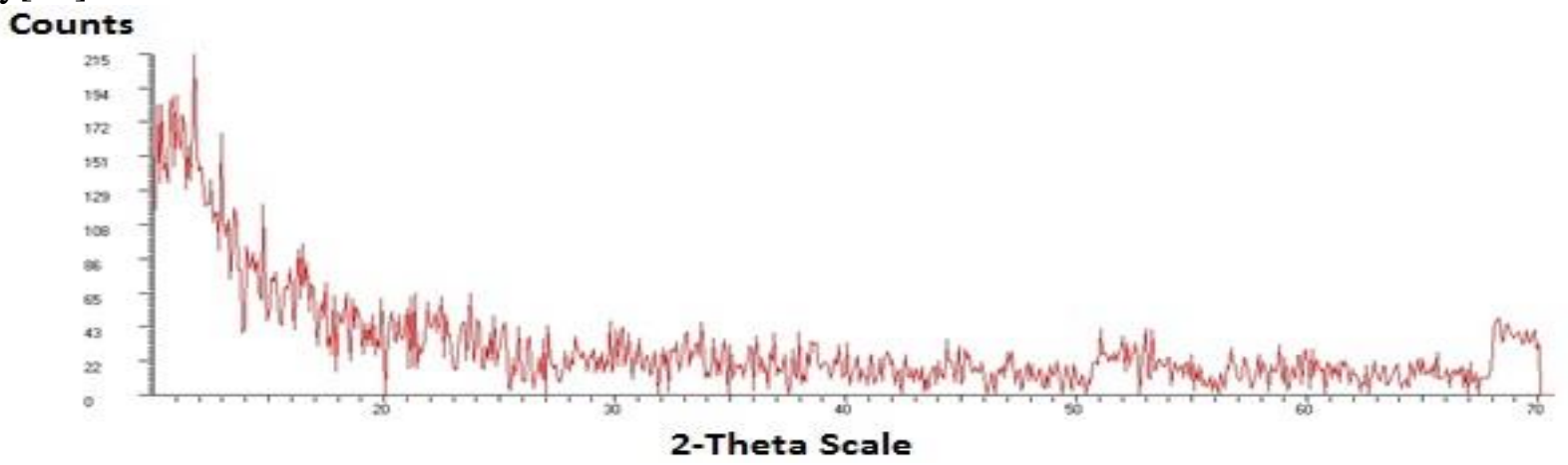

Figure8: X-Ray Diffraction of Rice Straw

\subsection{SEM results for Activated Carbon}

It was observed that Scanning electron microscopy images of $\mathrm{MgCl}_{2}$ based charcoal were a nano-composite material having un-homogenized morphology. At $100 \mu \mathrm{m}$ image showing the presence of $\mathrm{MgCl}_{2}$ while dark part identifies the existence of rice straw charcoal. There was no pore structure in images [39]. Figures are shown below.
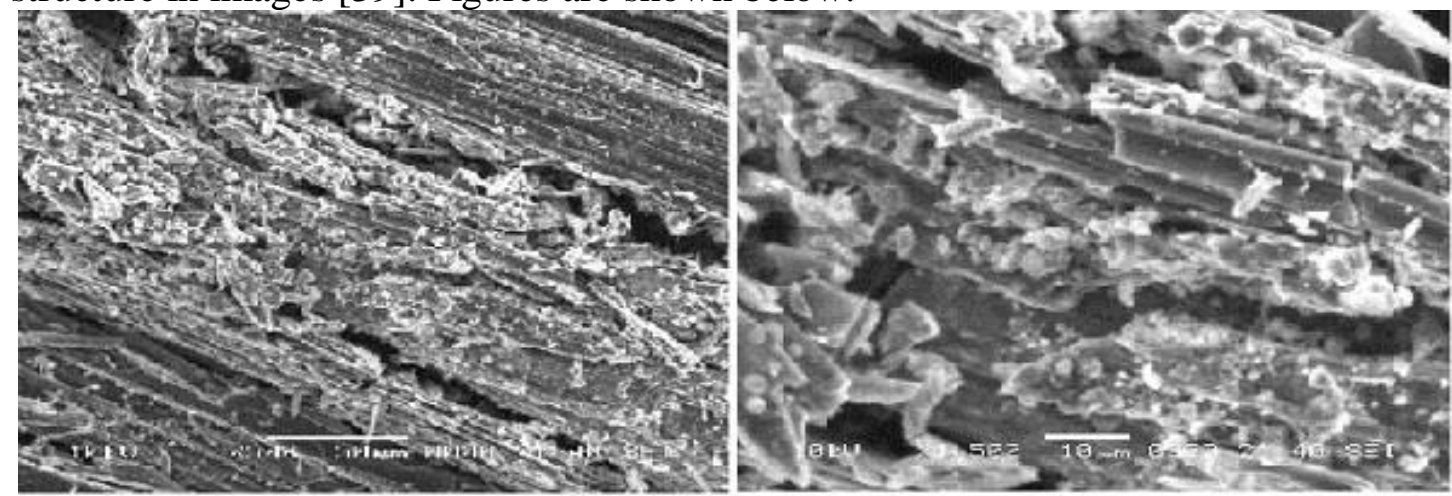

Figure 9:SEM images of activated carbon 


\subsection{SEM results for Rice Straw}

The SEM images of rice straw showing that it has a uniform structure was observed by Ceyhan[40]. Up to 3000 magnification sub-pores can be observed. The morphology of images and irregular shape with different kinds of ranges and smooth surface as identified by Cao [41].

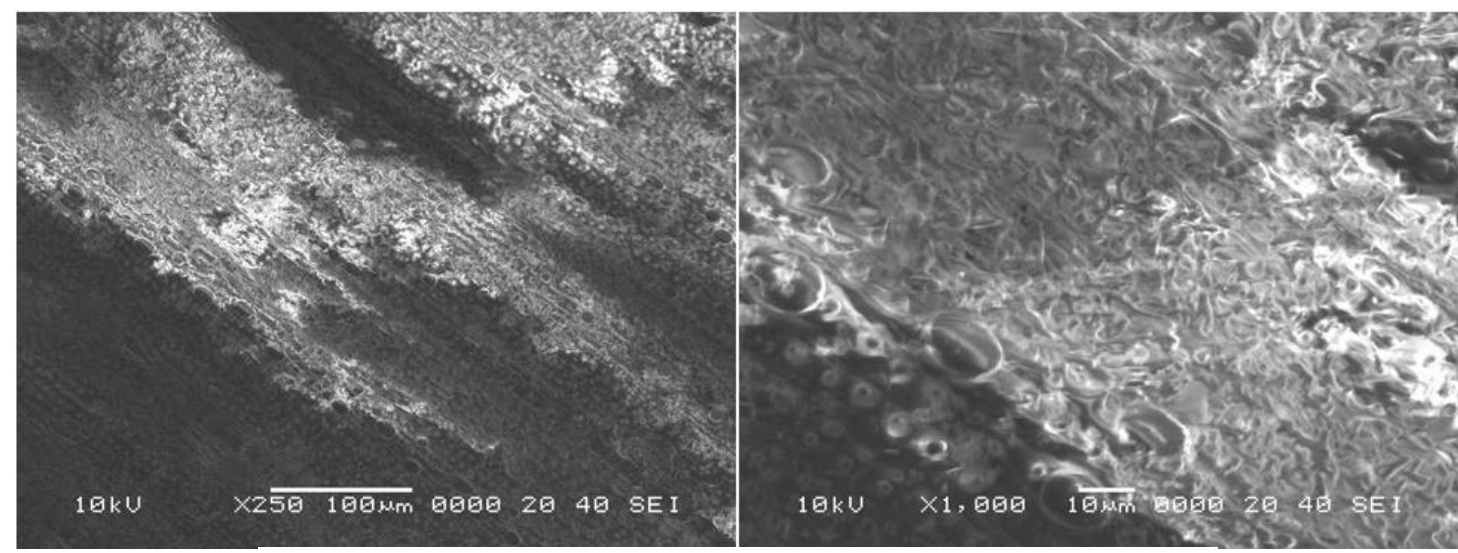

Figure 10: Scanning electron microscopy of rice straw

\section{CHARACTERISTICS OF SYNTHETIC GREY WATER}

The prepared synthetic grey water has $\mathrm{pH} 9.2$, turbidity is $26 \mathrm{NTU}, \mathrm{BOD}_{5}$ is $350 \mathrm{mg} / \mathrm{L}$, COD is $500 \mathrm{mg} / \mathrm{L}$, TSS is $435 \mathrm{mg} / \mathrm{L}$, Oil and Fats are $40 \mathrm{ppm}$ similar results were observed by [26],[42] and [43].

\subsection{Application of activated carbon on synthetic grey water}

The $\mathrm{pH}$ value after application has decreased up to 8.0 similar results were observed by [44]. While turbidity was decreased up to $89 \%$ and observed 3.8 NTU nearly same results were observed by [45]. $\mathrm{BOD}_{5}$ after application was observed $100 \mathrm{mg} / \mathrm{L}$ (77\% removal) and COD was decreased from $500 \mathrm{mg} / \mathrm{L}$ and reached at $175 \mathrm{mg} / \mathrm{L}(65 \%$ removal) as stated by [46] the produced activated carbon has capability to remove $\mathrm{BOD}_{5}$ and $\mathrm{COD}$ more than $75 \%$ and $60 \%$, respectively. TSS of synthetic grey water after application of activated carbon was observed 85 $\mathrm{mg} / \mathrm{L}$ ( $80 \%$ removal). Values of oil and fats were decreased from $40 \mathrm{ppm}$ to $4.5 \mathrm{ppm}$ which is nearly $89 \%$, similar results were observed by [47].

\subsection{Application of combined filter on synthetic grey water}

The $\mathrm{pH}$ value after application of combined filter has decreased up to 7.8, same results were observed by [48]. While turbidity was decreased up to 2.4 NTU (91\% removal), [49] observed nearly same results. Whereas $\mathrm{BOD}_{5}$ after application with combined filter was observed $27 \mathrm{mg} / \mathrm{L}$ (93\% removal), same as observed by [50]and COD was decreased from $500 \mathrm{mg} / \mathrm{L}$ to $52 \mathrm{mg} / \mathrm{L}$ (92\% removal), same results were concluded by, [51]. TSS of synthetic grey water after application of combinedfilter has become $110 \mathrm{mg} / \mathrm{L}$ (75\% removal), same as described by [52]. 
Substantial decrease was observed in the value of oil and fats from $40 \mathrm{ppm}$ up to $3.2 \mathrm{ppm}$ (93\% removal), results are related with [53].

Table 4: Comparison of efficiency of the both filters

\begin{tabular}{|l|c|c|c|}
\hline \multicolumn{1}{|c|}{ Parameters } & $\begin{array}{c}\text { SGW Initial } \\
\text { Results }\end{array}$ & $\begin{array}{c}\text { Treated with } \\
\text { activated carbon }\end{array}$ & $\begin{array}{c}\text { Treated with Combined Filters } \\
\text { (AC \& RS) }\end{array}$ \\
\hline $\mathrm{pH}$ & 9.2 & 8.0 & 7.8 \\
\hline $\mathrm{BOD}_{5}$ & $350 \mathrm{mg} / \mathrm{L}$ & $100 \mathrm{mg} / \mathrm{L}$ & $27 \mathrm{mg} / \mathrm{L}$ \\
\hline $\mathrm{COD}$ & $500 \mathrm{mg} / \mathrm{L}$ & $175 \mathrm{mg} / \mathrm{L}$ & $52 \mathrm{mg} / \mathrm{L}$ \\
\hline $\mathrm{TSS}$ & $435 \mathrm{mg} / \mathrm{L}$ & $85 \mathrm{mg} / \mathrm{L}$ & $110 \mathrm{mg} / \mathrm{L}$ \\
\hline Oil \& Fats & $40 \mathrm{ppm}$ & $4.5 \mathrm{ppm}$ & $3.2 \mathrm{ppm}$ \\
\hline Turbidity & $26 \mathrm{NTU}$ & $3.8 \mathrm{NTU}$ & $2.4 \mathrm{NTU}$ \\
\hline
\end{tabular}

\section{CONCLUSION}

The study has successfully provided a better way to utilize rice straw and to overcome the scarcity and depletion of freshwater in Pakistan. It was concluded that rice straw can be converted into activated carbon and low concentration greywater can be treated. Combined filter is more efficient than the activated carbon filter although FTIR results showed attachment of approximately same functional groups but XRD and SEM has further illustrated that the structure and shape is different in both the filters which has significant impact on its efficiency.

\section{Acknowledgement}

The authors are thankful to Mehran University of Engineering and Technology Jamshoro, Sindh Pakistan, to provide experimental and financial support for research work.

\section{REFERENCES}

[1] G. Pegram, "Global water scarcity: risks and challenges for business". Lloyd's, 32, 2010.

[2] C.J. Vörösmarty, P.B. McIntyre, M.O. Gessner, D. Dudgeon, A. Prusevich, P. Green, S. Glidden, S.E. Bunn, C.A. Sullivan, C.R. Liermann, and P.M. Davies, "Global threats to human water security and river biodiversity". Nature, 467(7315), pp.555-561, 2010.

[3] WWAP (United Nations World Water Assessment Programme)/UN-Water. The United Nations World Water Development Report 2018: Nature-Based Solutions for Water. Paris, UNESCO, 2018.

[4] John Briscoe and Usman Qamar, Pakistan's Water Economy: Running Dry (Oxford: World Bank and Oxford University Press, 2006), executive summary.

[5] WHO/UNICEF Joint Monitoring Programme for Water Supply and Sanitation (ISBN 92 4156202 1) (NLM classification: WA 675).

[6] D.M. Ghaitidak, and K.D Yadav, "Characteristics and treatment of greywater-A review". Environmental Science and Pollution Research, 20(5), pp.2795-2809, 2013. 
[7] E. Eriksson, K. Auffarth, M. Henze, and A. Ledin, "Characteristics of grey wastewater". Urban water, 4(1), pp.85-104, 2002.

[8] J.G. March, M. Gual, and F. Orozco, "Experiences on grey water re-use for toilet flushing in a hotel (Mallorca Island, Spain)", Desalination, 164(3), pp.241-247, 2004.

[9] K. Kujawa-Roeleveld, and G. Zeeman, "Anaerobic treatment in decentralised and sourceseparation-based sanitation concepts", Reviews in Environmental Science and Bio/Technology, 5(1), pp.115-139, 2006.

[10] R.N. Kulabako, M. Nalubega, E. Wozei, and R. Thunvik, "Environmental health practices, constraints and possible interventions in peri-urban settlements in developing countries-a review of Kampala, Uganda", International journal of environmental health research, 20(4), pp.231-257, 2010.

[11]F. Fu, and Q. Wang, "A review of removal of heavy metal ions from wastewaters", Journal of Environmental Management, 92(3), pp.407-418, 2011.

[12] S. Tangjuank, N. Insuk, J. Tontrakoon, and V. Udeye, "Adsorption of lead (II) and cadmium (II) ions from aqueous solutions by adsorption on activated carbon prepared from cashew nut shells", World Academy of Science, Engineering and Technology, 52, pp.110-116, 2009.

[13]D.C. Ko, E.L. Mui, K.S. Lau, and G. McKay, "Production of activated carbons from waste tire-process design and economical analysis", Waste Management, 24(9), pp.875888, 2004.

[14] S. Ismadji, and S.K. Bhatia, "Characterization of activated carbons using liquid phase adsorption", Carbon, 39(8), pp.1237-1250, 2001.

[15] L.Y. Hsu, and H. Teng, "Influence of different chemical reagents on the preparation of activated carbons from bituminous coal", Fuel Processing Technology, 64(1-3), pp.155166, 2000.

[16]T. Qiang, Z. Zhigang, Z. Wenpei, and C. Zidong, "SO2 and NO selective adsorption properties of coal-based activated carbons", Fuel, 84(4), pp.461-465, 2005.

[17] W. Qiao, Y. Korai, I. Mochida, Y. Hori, and T. Maeda, "Preparation of an activated carbon artifact: oxidative modification of coconut shell-based carbon to improve the strength", Carbon, 40(3), pp.351-358, 2002.

[18]M. Sekar, V. Sakthi, and S. Rengaraj, "Kinetics and equilibrium adsorption study of lead (II) onto activated carbon prepared from coconut shell", Journal of colloid and interface science, 279(2), pp.307-313, 2004.

[19] N. Tancredi, N. Medero, F. Möller, J. Píriz, C. Plada, and T. Cordero, "Phenol adsorption onto powdered and granular activated carbon, prepared from Eucalyptus wood", Journal of colloid and interface science, 279(2), pp.357-363, 2004.

[20] M. Kapoor, D. Panwar, and G.S. Kaira, "Bioprocesses for Enzyme Production Using Agro-Industrial Wastes: Technical Challenges and Commercialization Potential", In Agro-Industrial Wastes as Feedstock for Enzyme Production (pp. 61-93), 2016. Academic Press.

[21] A.M. Youssef, N.R.E. Radwan, I. Abdel-Gawad, and G.A.A. Singer, "Textural properties of activated carbons from apricot stones", Colloids and Surfaces A: Physicochemical and Engineering Aspects, 252(2-3), pp.143-151, 2005. 
[22] X.J. Jin, Z.M. Yu, and Y.U. Wu, "Preparation of activated carbon from lignin obtained by straw pulping by $\mathrm{KOH}$ and $\mathrm{K} 2 \mathrm{CO} 3$ chemical activation", Cellulose Chemistry and Technology, 46(1), p.79, 2012.

[23]P.R. Gawande, and D.J.P. Kaware, "Preparation and activation of activated carbon from waste materials-A review", International Journal for Research in Applied Science and Engineering Technology, 4, pp.1-4, 2016.

[24]C.H. Yun, Y.H. Park, and C.R. Park, "Effects of pre-carbonization on porosity development of activated carbons from rice straw", Carbon, 39(4), pp.559-567, 2001.

[25] M.F. Ali, A.R. Sahito, and A.A. Babar, "arsenic removal from groundwater by producing activated carbon from cotton gin trash (ac-cgt) - a case study of sakrand, district shaheed benazirabad, sindh, Pakistan, Journal of agricultural and environmental research, 4(3), pp. $169-175,2018$.

[26] A.A. Pathan, R.B. Mahar, and K. Ansari, "Preliminary study of greywater treatment through rotating biological contactor", Mehran University Research Journal of Engineering \& Technology, 30(3), pp.531-538, 2011.

[27]J. Coates, "Encyclopedia of analytical chemistry", Interpretation of infrared spectra, a practical approach. Wiley, Chichester, pp.10815-10837, 2000.

[28] M.S. Yeasmin, and M.I.H. Mondal, "Synthesis of highly substituted carboxymethyl cellulose depending on cellulose particle size", International journal of biological macromolecules, 80, pp.725-731, 2015.

[29] J.H. You, H.L. Chiang, and P.C. Chiang, "Comparison of adsorption characteristics for VOCs on activated carbon and oxidized activated carbon", Environmental progress, 13(1), pp.31-36, 1994.

[30]H. Javadian, and M. Taghavi, “Application of novel Polypyrrole/thiol-functionalized zeolite Beta/MCM-41 type mesoporous silica nanocomposite for adsorption of $\mathrm{Hg} 2+$ from aqueous solution and industrial wastewater: Kinetic, isotherm and thermodynamic studies", Applied Surface Science, 289, pp.487-494, 2014.

[31] T.I. Bhuiyan, J.K. Tak, S. Sessarego, D. Harfield, and J.M. Hill, "Adsorption of acidextractable organics from oil sands process-affected water onto biomass-based biochar: Metal content matters", Chemosphere, 168, pp.1337-1344, 2017.

[32] S.F. Sim, M. Mohamed, N.A.L.M.I. Lu, N.S.P. Sarman, and S.N.S. Samsudin, "Computer-assisted analysis of fourier transform infrared (FTIR) spectra for characterization of various treated and untreated agriculture biomass", BioResources, 7(4), pp. 5367-5380, 2012.

[33] X. Chen, J. Yu, Z. Zhang, and C. Lu, "Study on structure and thermal stability properties of cellulose fibers from rice straw", Carbohydrate polymers, 85(1), pp. 245-250, 2011.

[34] P. Aggarwal, D. Dollimore, and K. Heon, "Comparative thermal analysis study of two biopolymers, starch and cellulose", Journal of thermal analysis, 50(1-2), pp.7-17, 1997.

[35] A. Musa, M.B. Ahmad, M.Z. Hussein, and S.M. Izham, "Acid Hydrolysis-Mediated preparation of Nanocrystalline Cellulose from Rice Straw", International Journal Nanomater Nano technol Nano med, 3:051, (2017).

[36] T. Tay, S. Uçar, and S. Karagöz, "Preparation and characterization of activated carbon from waste biomass”, Journal of Hazardous Materials, 165(1-3), pp.481-485, 2009. 
[37]C.Lu, S. Xu, and C. Liu, "The role of $\mathrm{K} 2 \mathrm{CO} 3$ during the chemical activation of petroleum coke with KOH', Journal of Analytical and Applied Pyrolysis, 87(2), pp.282287, 2010.

[38] Y. He, Y. Pang, Y. Liu, X. Li, and K. Wang, "Physicochemical characterization of rice straw pretreated with sodium hydroxide in the solid state for enhancing biogas production", Energy \& Fuels, 22(4), pp.2775-2781, 2008.

[39] Y. Liu, X. Zhu, F. Qian, S. Zhang, J. Chen, "Magnetic activated carbon prepared from rice straw-derived hydrochar for triclosan removal", RSC Advances, 4(109), pp.6362063626., 2014.

[40] A.B. Nandiyanto, Z.A. Putra, R. Andika, M.R. Bilad, T. Kurniawan, R. Zulhijah, I. Hamidah, "Porous activated carbon particles from rice straw waste and their adsorption properties", Indonesian Journal of Science and Technology, 3(2), pp.82-94, 2017.

[41]X. Cao, L. Ma, B. Gao, and W. Harris, "Dairy-manure derived Biochar effectively sorbs lead and atrazine”, Environmental science \& technology, 43(9), pp.3285-3291, 2009.

[42] S.M.Kanawade, "Greywater Treatment in Pilot Plant and it's Reuse", International Journal of Chemical and Physical Sciences, 4(1), pp. 83-92, 2015.

[43] F. Nazim, and V. Meera, "Treatment of synthetic greywater using 5\% and 10\% garbage enzyme solution", Bonfring International Journal of Industrial Engineering and Management Science, 3(4), pp.111-117, 2013.

[44]M.A. Mohammad Razi, A. Al-Gheethi, M. Al-Qaini, and A. Yousef, "Efficiency of activated carbon from palm kernel shell for treatment of greywater", Arab Journal of Basic and Applied Sciences, 25(3), pp.103-110, 2018.

[45] M. Jawaduddin, S.A. Memon, N. Bheel, F. Ali, N. Ahmed, and A.W. Abro, "Synthetic Grey Water Treatment Through FeCl3-Activated Carbon Obtained from Cotton Stalks and River Sand", Civil Engineering Journal, 5(2), pp. 340-348, 2019.

[46] A.E.A. Nayl, R.A. Elkhashab, T. El Malah, S.M. Yakout, M.A. El-Khateeb, M.M. Ali, and H.M. Ali, "Adsorption studies on the removal of COD and BOD from treated sewage using activated carbon prepared from date palm waste", Environmental Science and Pollution Research, 24(28), pp.22284-22293, 2017.

[47]E.R.A.N. Friedler, and N.I. Galil, "On-site greywater reuse in multi-storey buildings: Sustainable solution for water saving”, In Int. Conf. on Efficient Use and Management of Urban Water.

[48]F.T. Ademiluyi, S.A. Amadi, and N.J. Amakama, "Adsorption and Treatment of Organic Contaminants using Activated Carbon from Waste Nigerian Bamboo", Journal of Applied Sciences and Environmental Management, 13(3), 2009.

[49] M. Chrispim, M.A. Nolasco, A. Santos, G.I. Silva-Neto, and N.S. Santana, "Water Resources Saving: A Possibly Contribution from a Greywater Collection, Treatment and Reuse", 2014, Online-Version: http://www.tropentag.de.

[50]M.H. Al-Mughalles, R.A. Rahman, F.B. Suja, M. Mahmud, and S.M.S. Abdullah, "Greywater treatment using GAC biofilm reactor and sand filter system", Australian Journal of Basic and Applied Sciences, 6(3), pp. 283-292, 2012.

[51]M. Nasr, M. Ateia, and K. Hassan, "Artificial intelligence for greywater treatment using electrocoagulation process", Separation Science and Technology, 51(1), pp. 96-105, 2016. 
International Journal of Agriculture, Environment and Bioresearch

Vol. 4, No. 04; 2019

ISSN: $2456-8643$

[52] S. Singh, "Study of waste water effluent characteristics generated from paper industries", Journal of Basic and Applied Engineering Research, 2(17), pp. 1505-1509, 2015.

[53] S. Bhatti, Z. Siddiqui, S. Memon, I. Kandhir, M. Memon, \& A W, M. A. H. E. S. A. R., "Analysis and Treatment Wash off Water from Vehicular Service Station in Hyderabad", Sindh University Research Journal-SURJ (Science Series), 49(3), pp. 473-478, 2017. 